\title{
Off-Label Thrombolysis for Acute Ischemic Stroke: Rate, Clinical Outcome and Safety Are Influenced by the Definition of 'Minor Stroke'
}

\author{
L. Breuer C. Blinzler H.B. Huttner I.C. Kiphuth S.Schwab M. Köhrmann
}

Department of Neurology, University of Erlangen-Nuremberg, Erlangen, Germany

\section{Key Words}

Acute ischemic stroke $\cdot$ Thrombolysis $\cdot$ Off-label use $\cdot$

Minor stroke

\begin{abstract}
Background: Several contraindications for intravenous thrombolysis are not based on controlled trials. Specialized stroke centers often apply less restrictive criteria. The aim of our study was to analyze how many patients at our institution receive off-label thrombolysis. In addition, clinical outcome and safety data were compared to those from patients treated on-label, and the influence of different definitions of 'minor stroke' were examined. Methods: Consecutive thrombolysis patients treated between January 2006 and January 2010 were included. Patients treated off-label were compared to patients given on-label therapy according to the European license. Since no specified definition for 'minor neurological deficit' exists in the license, two distinct definitions were considered off-label, i.e. National Institutes of Health Stroke Scale score (NIHSSS) $<1$ (definition 1) and NIHSSS $\leq 4$ (definition 2). Results: Of a total of 422 patients, 232 (55\%) were treated off-label. The most prevalent off-label criteria (OLCs) were the following: age $>80$ years $(n=113)$, minor stroke (definition $1, n=3$; definition $2, n=84$ ), elevated
\end{abstract}

blood pressure necessitating aggressive treatment $(n=75)$, time window $>3 h(n=71)$ and major surgery or trauma within the preceding 3 months $(n=20)$. In group comparisons, off-label patients had an overall worse outcome using definition 1 for minor stroke, while there was no difference when definition 2 was applied. In multivariate analysis, off-label therapy (definition 1) in general and age $>80$ years were independent predictors of poor outcome. None of the contraindications were associated with an increased bleeding risk. Conclusions: Off-label therapy is frequently applied at our center and is not associated with higher complication rates. Overall outcome of off-label treatment largely depends on the definition used for minor stroke. Besides age $>80$ years, a known poor prognostic factor, no other specific OLC was associated with poor outcome. Our data suggest that the criteria in the European license may be too restrictive.

Copyright $\odot 2011$ S. Karger AG, Basel

\section{Introduction}

Multiple contraindications for thrombolysis with tissue plasminogen activator (tPA) have hampered the wider use of this therapy for patients with acute ischemic stroke. Several of those contraindications have not been

\section{KARGER}

Fax +41613061234 E-Mail karger@karger.ch www.karger.com
(C) 2011 S. Karger AG, Basel

$1015-9770 / 11 / 0322-0177 \$ 38.00 / 0$

Accessible online at:

www.karger.com/ced
PD Dr. Martin Köhrmann

Department of Neurology, University of Erlangen-Nuremberg

Schwabachanlage 6

DE-91054 Erlangen (Germany)

Tel. +499131 854 4544, E-Mail martin.koehrmann@uk-erlangen.de 
systematically studied and are not directly derived from the inclusion and exclusion criteria of the pivotal and approval-relevant randomized controlled trials. On the contrary, they were introduced on the basis of subgroup analyses or even expert opinions to putatively maximize the safety of the treatment in the initial phase of clinical implementation and thus might be overrestrictive for further clinical use. In addition, existing guidelines as well as official licenses vary in different parts of the world. For instance, influenced by the early European Cooperative Acute Stroke Study (ECASS) trials [1, 2], an upper age limit of 80 years for thrombolysis in Europe was defined, while no such limit exists in the USA. There are few data available on the outcome and safety of treatment in the case of the various off-label criteria (OLCs). Based on increasing clinical experience and several observational studies, an increasing number of experienced stroke centers follow their own less restrictive thrombolysis protocols rather than adhering rigidly to the official licenses for tPA $[3,4]$. The aim of our study was to analyze how many patients at our institution receive off-label thrombolysis according to the European license. Furthermore, clinical outcome and safety data [intracerebral hemorrhage $(\mathrm{ICH})$ rates] were compared to those of patients treated on-label, and the influence of different definitions of 'minor stroke' in this context were examined.

\section{Materials and Methods}

The Erlangen Stroke and Thrombolysis Database is a prospective database of all patients with acute ischemic stroke treated at our institution (University Hospital Erlangen, Germany). It contains baseline demographic and stroke-related data as well as treatment specifics, imaging information and outcome parameters for each stroke patient. Outcome at day 90 was assessed using the Modified Rankin Scale (mRS) evaluated by a neurologist as part of the general database independently from the present study using a semistructured interview either in person or by telephone. Favorable clinical outcome was defined as mRS 0-2 and/or clinical recovery to the prestroke mRS. Four patients were lost to follow-up at day 90. Asymptomatic ICH and symptomatic ICH (sICH) were defined according to the ECASS-3 criteria [5].

\section{Study Population}

For this study, we extracted data for all patients with acute ischemic stroke from this database who received intravenous thrombolysis (IVT) in our institution between January 2006 and January 2010. All patients with basilar artery occlusion and all patients who received either intra-arterial thrombolysis or combined intra-arterial thrombolysis/IVT (bridging) were excluded. Our institutional guidelines are less restrictive than the European Medicines Agency license for tPA (see table 1 for a detailed protocol). Treatment within $3 \mathrm{~h}$ ( $4.5 \mathrm{~h}$ according to ECASS-3) is based on noncontrast CT only, while treatment in an extended time window is based on MRI criteria as described previously [6]. Patients treated off-label were identified, and outcome and safety data were compared to those of patients who received on-label therapy. Since no specified definition of 'minor neurological deficit' is given in the European or US license for tPA, two distinct definitions were considered 'off-label' for the purposes of this study: National Institutes of Health Stroke Scale score (NIHSSS) $<1$ on admission (definition 1 ), and NIHSSS $\leq 4$ on admission (definition 2).

All patients were treated and monitored at our stroke unit according to European guidelines [7]. All patients received either CT or MRI at 24-36 h to evaluate hemorrhagic complications. Informed consent was obtained from the patient or next of kin in the case of off-label IVT in any case, and the thrombolysis protocol was approved by our institutional ethics committee.

\section{Statistical Analysis}

Statistical analyses were performed using the 'SPSS' software package (version 18.0, SSPS Inc.). All data were tested for normality and are given as medians and range or means and SD, as appropriate. Categorical variables are presented as frequencies and percentages. The groups of on- and off-label patients were compared using the Mann-Whitney U test, $\chi^{2}$ test and Fisher's exact test. Multivariate regression analyses were performed separately for poor clinical outcome, sICH and mortality using a backward stepwise regression model. For each OLC demonstrating at least a trend $(\mathrm{p}<0.1)$ with regard to the chosen end point in univariate analysis, a separate model was calculated introducing established predictors (age, NIHSSS at baseline) for the outcome and safety of thrombolysis. In addition, all models were adjusted for baseline variables. For all analyses, a 2 -tailed $p$ value $\leq 0.05$ was considered statistically significant.

\section{Results}

\section{Baseline Characteristics}

Between January 2006 and January 2010, a total of 422 patients received IVT. Baseline characteristics of all patients and comparison of on- and off-label thrombolysis using the two different definitions for minor strokes are shown in table 2. Independently of the definition used, patients treated off-label were older, had higher blood pressure on hospital admission and were more likely to have a history of arterial hypertension, atrial fibrillation and previous strokes. The rate of cardioembolic strokes was higher and the time window (symptom to needle time) was longer in the off-label groups.

\section{Off-Label Thrombolysis}

Overall, 232 of 422 IVT patients (55\%) received offlabel thrombolysis according to definition 1 (minor stroke $=$ NIHSSS $=0)$ and $270(64 \%)$ according to definition 2 (minor stroke $=$ NIHSSS $\leq 4)$. The annualized rates 
Table 1. Off-label criteria according to the European Medicines Agency (2002), our institutional approach and the rate of individual contraindications in our cohort $(\mathrm{n}=422)$

\begin{tabular}{|c|c|c|c|c|}
\hline \multirow[t]{2}{*}{$\begin{array}{l}\text { Contraindications as per European Medicines } \\
\text { Agency license }\end{array}$} & \multirow{2}{*}{$\begin{array}{l}\text { Applied } \\
\text { at our } \\
\text { institution }\end{array}$} & \multirow[t]{2}{*}{ Treatment guideline for intravenous thrombolysis at our institution } & \multicolumn{2}{|c|}{$\begin{array}{l}\text { Rate of individual } \\
\text { contraindications }\end{array}$} \\
\hline & & & $\mathrm{n}$ & $\%$ \\
\hline Age $<18$ years, $>80$ years & no & $\begin{array}{l}\text { patients }>80 \text { years are treated; patients }<18 \text { years are treated at the } \\
\text { Pediatrics Department and were not included in this study }\end{array}$ & 113 & 26.8 \\
\hline Intravenous treatment of blood pressure & no & \multirow{2}{*}{$\begin{array}{l}\text { patients with elevated blood pressure receive intravenous treatment } \\
\text { before thrombolysis }\end{array}$} & \multirow[t]{2}{*}{75} & \multirow[t]{2}{*}{17.9} \\
\hline Blood pressure $>185 \mathrm{~mm} \mathrm{Hg}$ & (yes) & & & \\
\hline Symptom to needle time $>3 \mathrm{~h}$ & no & $\begin{array}{l}\text { patients are treated up to } 4.5 \mathrm{~h} \text { according to ECASS- } 3 \text { criteria, } \\
\text { otherwise treatment }>3 \mathrm{~h} \text { is based on MRI selection criteria }\end{array}$ & 71 & 17.4 \\
\hline Oral anticoagulation & (yes) & patients are treated up to an INR of $\leq 1.7$ & 22 & 5.2 \\
\hline Major surgery $<3$ months & no & \multirow{3}{*}{ individual decision by the treating physician } & \multirow{3}{*}{20} & \multirow{3}{*}{4.7} \\
\hline Significant trauma $<3$ months & no & & & \\
\hline Serious head trauma $<3$ months & no & & & \\
\hline Previous stroke and diabetes & no & & 9 & 2.1 \\
\hline Severe stroke (NIHSSS on admission $>25$ ) & no & & 5 & 1.2 \\
\hline Previous stroke $<3$ months & no & patients are not treated only if imaging shows subacute infarction & 4 & 0.9 \\
\hline $\begin{array}{l}\text { Minor neurological deficit } \\
(\text { defined as NIHSSS }=0)\end{array}$ & no & $\begin{array}{l}\text { functionally disabling symptoms are treated regardless of the NIHSSS; } \\
\text { decision can also be based on imaging information }\end{array}$ & 3 & 0.7 \\
\hline $\begin{array}{l}\text { Minor neurological deficit } \\
\text { (defined as NIHSSS } \leq 4 \text { ) }\end{array}$ & no & $\begin{array}{l}\text { functionally disabling symptoms are treated regardless of the NIHSSS; } \\
\text { decision can also be based on imaging information }\end{array}$ & 84 & 19.9 \\
\hline Platelet count $<100 \times 10^{3} / \mu \mathrm{l}$ & no & $\begin{array}{l}\text { patients are usually treated with tPA before the laboratory results are } \\
\text { available (except point-of-care testing of blood glucose and INR) }\end{array}$ & 2 & 0.5 \\
\hline Bacterial endocarditis, pericarditis & yes & no ultrasound screening for endocarditis or pericarditis is applied & 1 & 0.2 \\
\hline Rapidly improving symptoms & no & $\begin{array}{l}\text { patients are treated once a functionally disabling deficit is detected } \\
\text { irrespective of the development of the NIHSSS }\end{array}$ & - & - \\
\hline Glucose $<50 \mathrm{mg} / \mathrm{dl},>400 \mathrm{mg} / \mathrm{dl}$ & no & $\begin{array}{l}\text { patients are treated after treatment of very low and very high values } \\
\text { of blood glucose }\end{array}$ & - & - \\
\hline Epileptic seizure at onset & no & once diagnosis is confirmed (additional imaging) & - & - \\
\hline $\begin{array}{l}\text { History of intracranial neoplasm, AVM or } \\
\text { aneurysm }\end{array}$ & no & individual decision by the treating physician & - & - \\
\hline Intracranial or spinal surgery & no & individual decision by the treating physician & - & - \\
\hline History of intracranial hemorrhage & no & individual decision by the treating physician & - & - \\
\hline History of SAH from aneurysm & no & individual decision by the treating physician & - & - \\
\hline $\mathrm{ICH}$ on $\mathrm{CT}$ & yes & & - & - \\
\hline Suspected SAH even if imaging normal & yes & & - & - \\
\hline Severe stroke on imaging (>1/3 MCA territory) & yes & & - & - \\
\hline Heparin/LMWH with high APTT & yes & & - & - \\
\hline Current bleeding diathesis & yes & & - & - \\
\hline Neoplasms with increased bleeding risk & yes & & - & - \\
\hline Traumatic external heart massage $<10$ days & yes & & - & - \\
\hline $\begin{array}{l}\text { Puncture of noncompressible } \\
\text { blood vessel }<10 \text { days }\end{array}$ & yes & & - & - \\
\hline Obstetric delivery $<10$ days & yes & & - & - \\
\hline Ulcerative gastrointestinal disease & yes & & - & - \\
\hline Esophageal varices & yes & & - & - \\
\hline Acute pancreatitis & yes & & - & - \\
\hline Severe liver disease & yes & & - & - \\
\hline
\end{tabular}

$\mathrm{AVM}=$ Arteriovenous malformation; $\mathrm{SAH}=$ subarachnoid hemorrhage; $\mathrm{MCA}=$ middle cerebral artery; $\mathrm{LMWH}=$ low-molecular weight heparin; APTT $=$ activated partial prothrombin time; INR = International Normalized Ratio. 
Table 2. Baseline characteristics of all patients $(n=422)$ comparing on- and off-label thrombolysis using different off-label definitions

\begin{tabular}{|c|c|c|c|c|c|c|c|}
\hline & $\begin{array}{l}\text { All patients } \\
(\mathrm{n}=422 ; 100 \%)\end{array}$ & $\begin{array}{l}\text { Off-label } \\
\text { definition } 1^{\text {a }} \\
(\mathrm{n}=232 ; 55 \%)\end{array}$ & $\begin{array}{l}\text { On-label } \\
\text { definition } 1^{\mathrm{a}} \\
(\mathrm{n}=190 ; 45 \%)\end{array}$ & $\begin{array}{l}\text { p value } \\
\text { defini- } \\
\text { tion } 1^{\text {a }}\end{array}$ & $\begin{array}{l}\text { Off-label } \\
\text { definition } 2^{\mathrm{b}} \\
(\mathrm{n}=270 ; 64 \%)\end{array}$ & $\begin{array}{l}\text { On-label } \\
\text { definition } 2^{\mathrm{b}} \\
(\mathrm{n}=152 ; 36 \%)\end{array}$ & $\begin{array}{l}\mathrm{p} \text { value } \\
\text { definition } \\
2^{\mathrm{b}}\end{array}$ \\
\hline Age, years & $73(63-81)$ & $79(69-84)$ & $67(58-75)$ & 0.000 & $77(66-84)$ & $68(60-75)$ & 0.000 \\
\hline Males, $\mathrm{n}$ & $233(55.2)$ & $115(49.6)$ & $118(62.1)$ & 0.010 & $142(52.4)$ & $91(60.3)$ & 0.119 \\
\hline \multicolumn{8}{|l|}{ Risk factors, $\mathrm{n}$} \\
\hline Hypertension & $351(83.2)$ & $205(88.4)$ & $146(76.8)$ & 0.002 & $238(87.8)$ & $113(74.8)$ & 0.001 \\
\hline Hypercholesterolemia & $229(54.3)$ & $116(50)$ & $113(59.5)$ & 0.052 & $143(52.8)$ & $86(57)$ & 0.408 \\
\hline Diabetes & $146(34.6)$ & $81(34.9)$ & $65(34.2)$ & 0.880 & $93(34.3)$ & $53(35.1)$ & 0.871 \\
\hline Coronary artery disease & $103(24.5)$ & $57(24.2)$ & $46(24.2)$ & 0.892 & $68(25.3)$ & $35(23.2)$ & 0.631 \\
\hline Atrial fibrillation & $179(42.4)$ & $129(55.6)$ & $50(26.3)$ & $<0.001$ & $131(48.3)$ & $48(31.8)$ & 0.001 \\
\hline Previous stroke & $72(17.1)$ & $50(21.6)$ & $22(11.6)$ & 0.006 & $55(20.4)$ & $17(11.3)$ & 0.017 \\
\hline Nicotine & $54(12.8)$ & $24(10.3)$ & $30(15.8)$ & 0.096 & $31(11.4)$ & $23(15.2)$ & 0.264 \\
\hline Previous myocardial infarction & $42(10.0)$ & $23(10.1)$ & $19(10)$ & 0.988 & $25(9.3)$ & $17(11.3)$ & 0.512 \\
\hline Peripheral artery disease & $46(10.9)$ & $23(10.1)$ & $23(12.1)$ & 0.482 & $30(11.1)$ & $16(10.6)$ & 0.871 \\
\hline Systolic blood pressure, $\mathrm{mm} \mathrm{Hg}$ & $160(145-177)$ & $163(148-186.5)$ & $155(140-170)$ & 0.000 & $162(147-185)$ & $153(139-170)$ & 0.000 \\
\hline Diastolic blood pressure, $\mathrm{mm} \mathrm{Hg}$ & $88(77-100)$ & $90(78-100)$ & $85(75-95)$ & 0.002 & $90(79-100)$ & $85(75-92.5)$ & 0.001 \\
\hline Temperature, ${ }^{\circ} \mathrm{C}$ & $36.9(36.5-37.3)$ & $37.0(36.5-37.3)$ & $36.9(36.5-37.3)$ & 0.776 & $37.0(36.5-37.3)$ & $36.9(36.5-37.3)$ & 0.220 \\
\hline \multicolumn{8}{|l|}{ Laboratory parameters } \\
\hline INR & $1.02(0.98-1.09)$ & $1.05(0.99-1.12)$ & $1.0(0.95-1.05)$ & 0.000 & $1.04(0.99-1.11)$ & $1.00(0.96-1.06)$ & 0.000 \\
\hline Leukocytes, $\times 10^{3} / \mu \mathrm{l}$ & $8.5(6.74-10.63)$ & $8.6(6.96-10.55)$ & $8.3(6.55-10.63)$ & 0.213 & $8.5(6.9-10.2)$ & $8.5(6.6-10.8)$ & 0.696 \\
\hline Platelet count, $\times 10^{3} / \mu \mathrm{l}$ & $239(197-298)$ & $240(201.5-299)$ & $194(198-298)$ & 0.837 & $237(197-292)$ & $243(197-301)$ & 0.679 \\
\hline $\mathrm{CRP}, \mathrm{mg} / \mathrm{l}$ & $4.8(2.0-10.4)$ & $5(2.0-13.4)$ & $3.85(0.7-8.1)$ & 0.001 & $5(2-12)$ & $4(0.8-9)$ & 0.031 \\
\hline \multicolumn{8}{|l|}{ Previous prophylactic treatment, $\mathrm{n}$} \\
\hline ASA & $152(36.4)$ & $94(40.9)$ & $58(30.9)$ & 0.041 & $104(38.8)$ & $48(32.0)$ & 0.170 \\
\hline Clopidogrel & $21(5)$ & $13(5.7)$ & $8(4.3)$ & 0.654 & $15(5.6)$ & $6(4)$ & 0.498 \\
\hline ER-DP/ASA & $5(1.2)$ & $4(1.7)$ & $1(0.5)$ & 0.384 & $4(1.5)$ & $1(0.7)$ & 0.658 \\
\hline Oral anticoagulation & $23(5.5)$ & $23(10)$ & 0 & $<0.001$ & $23(8.6)$ & 0 & 0.000 \\
\hline No previous antiplatelet treatment & $213(50.5)$ & $120(63.8)$ & $93(40.4)$ & 0.624 & $119(44.4)$ & $94(62.7)$ & 0.001 \\
\hline Glucose at baseline, $\mathrm{mg} / \mathrm{dl}$ & $114(98-141)$ & $117(100-140)$ & $110.5(94-140)$ & 0.114 & $113(98-139)$ & $113(97-144)$ & 0.626 \\
\hline Cholesterol at baseline, $\mathrm{mg} / \mathrm{dl}$ & $196.08 \pm 45.7$ & $191.3 \pm 43.3$ & $201.8 \pm 47.6$ & 0.022 & $197.7 \pm 44.2$ & $200.4 \pm 48.3$ & 0.152 \\
\hline \multicolumn{8}{|l|}{ NIHSSS } \\
\hline Baseline & $9(5-15)$ & $9(5-15)$ & $8(5-13)$ & 0.039 & $8(4-14)$ & $10(6-14)$ & 0.005 \\
\hline After $24 \mathrm{~h}$ & $6(2-14)$ & $6(2-14)$ & $4(1-11)$ & 0.002 & $5(2-12)$ & $6(2-13)$ & 0.493 \\
\hline At discharge & $4(1-11)$ & $5(1-12)$ & $2(0-9)$ & 0.001 & $4(1-11)$ & $4(1-10)$ & 0.992 \\
\hline \multicolumn{8}{|l|}{ TOAST criteria, $\mathrm{n}$} \\
\hline Large vessel & $30(7.1)$ & $12(5.2)$ & $18(9.5)$ & 0.127 & $18(6.7)$ & $12(7.9)$ & 0.694 \\
\hline Embolic & $183(43.4)$ & $130(56)$ & $53(28)$ & $<0.001$ & $135(50)$ & $48(31.8)$ & 0.000 \\
\hline Micro/lacunar & $2(0.5)$ & 0 & $2(1.1)$ & 0.202 & $1(0.4)$ & $1(0.7)$ & 1.000 \\
\hline Other & $23(5.5)$ & $8(3.4)$ & $15(7.9)$ & 0.001 & $10(3.7)$ & $13(8.6)$ & 0.044 \\
\hline Unknown & $183(43.4)$ & $82(35.3)$ & $101(53.4)$ & $<0.001$ & $106(39.3)$ & $77(51)$ & 0.025 \\
\hline Symptom to needle time, $\min$ & $120(90-180)$ & $130(90-210)$ & $110(85-150)$ & 0.000 & $125(90-195)$ & $107.5(85-150)$ & 0.000 \\
\hline
\end{tabular}

Values represent medians (interquartile ranges), numbers (percentages) or means \pm SD, as appropriate. $p$ values in bold are significant. INR $=$ International Normalized Ratio; CRP = C-reactive protein; ASA = acetylsalicylic acid; ER-DP = extended release dipyridamole; TOAST = Trial of Org 10172 in Acute Stroke Treatment.

${ }^{\mathrm{a}}$ Definition 1: NIHSSS $<1$ on admission, i.e. minor stroke $=$ NIHSSS $=0 .{ }^{\mathrm{b}}$ Definition 2: NIHSSS $\leq 4$ on admission, i.e. minor stroke $=$ NIHSSS $\leq 4$.

of off-label thrombolysis for the period between January 2006 and January 2010 are given in figure 1. The rate of off-label treatment did not change significantly over the examined years. The most frequent OLCs were age $>80$ years $(\mathrm{n}=113,26.8 \%)$, blood pressure $>185 / 110 \mathrm{~mm} \mathrm{Hg}$ combined with intravenous use of antihypertensives before treatment ( $\mathrm{n}=75,17.9 \%)$, symptom onset to needle time $>3 \mathrm{~h}(\mathrm{n}=71,17.4 \%)$ and major surgery or severe trauma within the preceding 3 months ( $n=20,4.7 \%)$. In- formation on all individual license contraindications is shown in table 1. Several of the other European Medicines Agency contraindications listed in table 1 did not occur in our study population, e.g. age $<18$ years (this patient group is by definition treated at the Pediatrics Department at our institution), epileptic seizure at stroke onset and glucose level at admission $<50$ or $>400 \mathrm{mg} / \mathrm{dl}$. Depending on the definition used, there is a clear difference in the number of minor strokes; thus, using defini- 
Fig. 1. Annual rates of on- and off-label thrombolysis for the years between January 2006 and January 2010. Front columns: using definition 1 (Def. 1) for minor strokes. Back columns: using definition 2 (Def. 2).

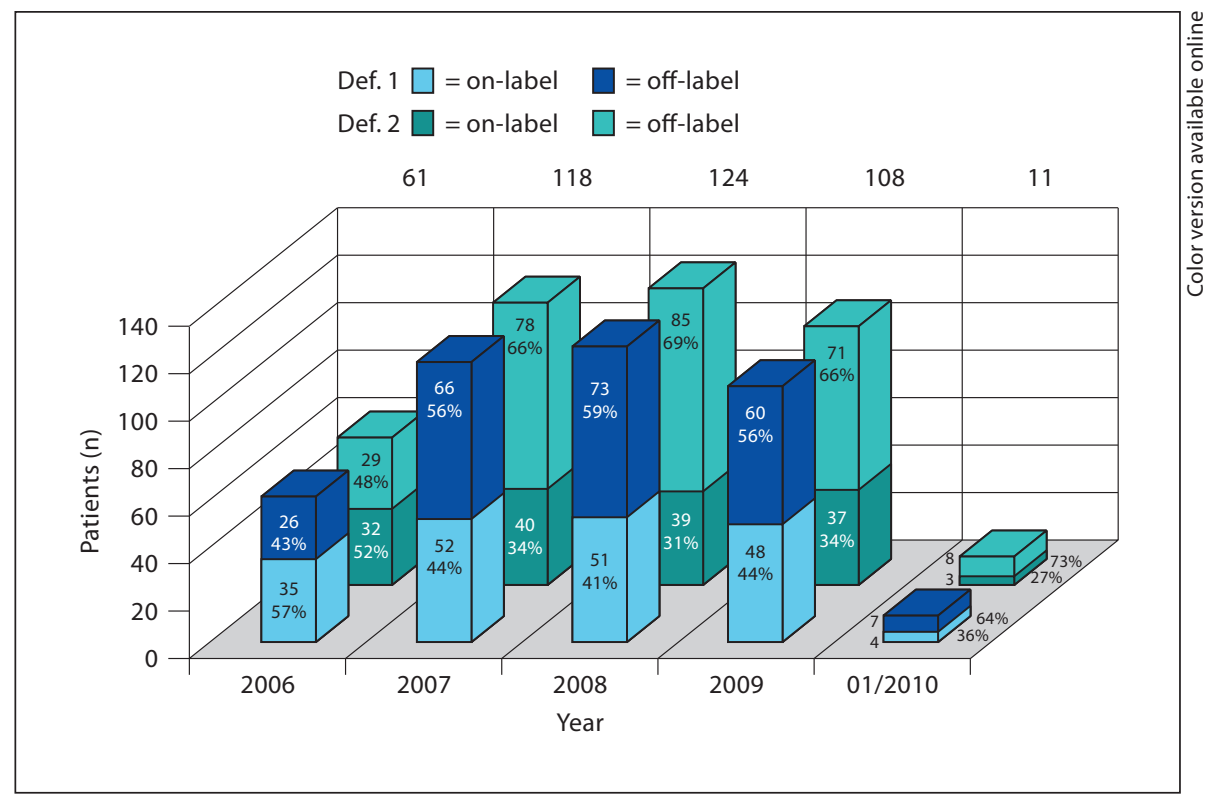

tion 1 , minor stroke occurred in only 3 cases $(0.7 \%)$, while using definition 2 resulted in 84 cases (19.9\%).

\section{Comparison of Clinical Outcome between Off-and}

On-Label Thrombolysis

Group comparison of clinical outcome between offand on-label thrombolysis showed differing results depending on the definition of minor stroke within the off-label criteria. Using definition 1 (defining only NIHSSS $=0$ as off-label), there was a significant difference between these two groups, with fewer patients with a good clinical outcome in the off-label group (table 3). No such difference was present applying definition 2 (defining NIHSSS $\leq 4$ as off-label).

Since this difference was only apparent when definition 1 was used, we performed a multivariate regression analysis to detect independent predictors for poor outcome on this basis. Of all contraindications (using definition 1), age $>80$ years [odds ratio (OR) $2.34,95 \%$ confidence interval (CI) 1.49-3.67; $\mathrm{p}<0.001]$, previous stroke and diabetes (OR 8.28, 95\% CI 1.03-66.79; $\mathrm{p}=0.047)$ and off-label therapy in general (OR 2.52, 95\% CI 1.70-3.74; $\mathrm{p}<0.001$ ) were relevant factors for poor clinical outcome in a univariate regression analysis. Age $>80$ years and offlabel therapy were independent predictors in the multivariate regression model (adjusted for relevant baseline parameters) for poor outcome at day 90 (OR 1.94, 95\% CI 1.16-3.24; $\mathrm{p}=0.012$, and OR 2.56, 95\% CI 1.62-4.06; $\mathrm{p}<$ 0.001 , respectively; table 4 ).

Off-Label Thrombolysis and Minor Stroke

\section{Comparison of Mortality between Off- and On-Label} Thrombolysis

Results of group comparison for mortality in patients treated off- and on-label were similar to the analysis of clinical outcome. Using definition 1 , the mortality rate in the off-label group was significantly higher than in the on-label group, while no such difference existed when using definition 2 (table 3 ). Though significantly associated in a univariate regression analysis, neither age $>80$ years nor off-label therapy in general were independent predictors for mortality in the multivariate regression analysis (table 4).

\section{Comparison of sICH between Off- and On-Label \\ Thrombolysis}

Independently of the definition of minor stroke within the OLCs, there was no significant difference in the number of sICHs between on- and off-label patients (table 3).

For sICH, none of the license contraindications was revealed either as a relevant factor in the univariate regression analysis or as an independent predictor in the multivariate analysis. Even off-label thrombolysis in general was not significantly associated with a higher number of sICHs or poor outcome (table 4).

\section{Outcome and Safety Depending on the Number of Concomitant OLCs}

Of the 422 patients, 159 (37.7\%) had 1 contraindication for thrombolytic therapy (using definition 1), 61 patients

Cerebrovasc Dis 2011;32:177-185 
Table 3. Outcome and safety parameters of all patients $(n=422)$ comparing on- and off-label thrombolysis using different off-label definitions

\begin{tabular}{lllllll}
$\begin{array}{l}\text { All patients } \\
(\mathrm{n}=422 ; 100 \%)\end{array}$ & $\begin{array}{l}\text { Off-label }_{\text {definition 1 }}^{\mathrm{a}} \\
(\mathrm{n}=232 ; 55 \%)\end{array}$ & $\begin{array}{l}\text { On-label } \\
\text { definition } 1^{\mathrm{a}} \\
(\mathrm{n}=190 ; 45 \%)\end{array}$ & $\begin{array}{l}\mathrm{p} \text { value } \\
\text { definition } 1^{\mathrm{a}}\end{array}$ & $\begin{array}{l}\text { Off-label } \\
\text { definition 2 } \\
(\mathrm{n}=270 ; 64 \%)\end{array}$ & $\begin{array}{l}\text { On-label } \\
\text { definition } 2^{\mathrm{b}} \\
(\mathrm{n}=152 ; 36 \%)\end{array}$ & $\begin{array}{l}\mathrm{p} \mathrm{value} \\
\text { definition } \\
2^{\mathrm{b}}\end{array}$ \\
\hline
\end{tabular}

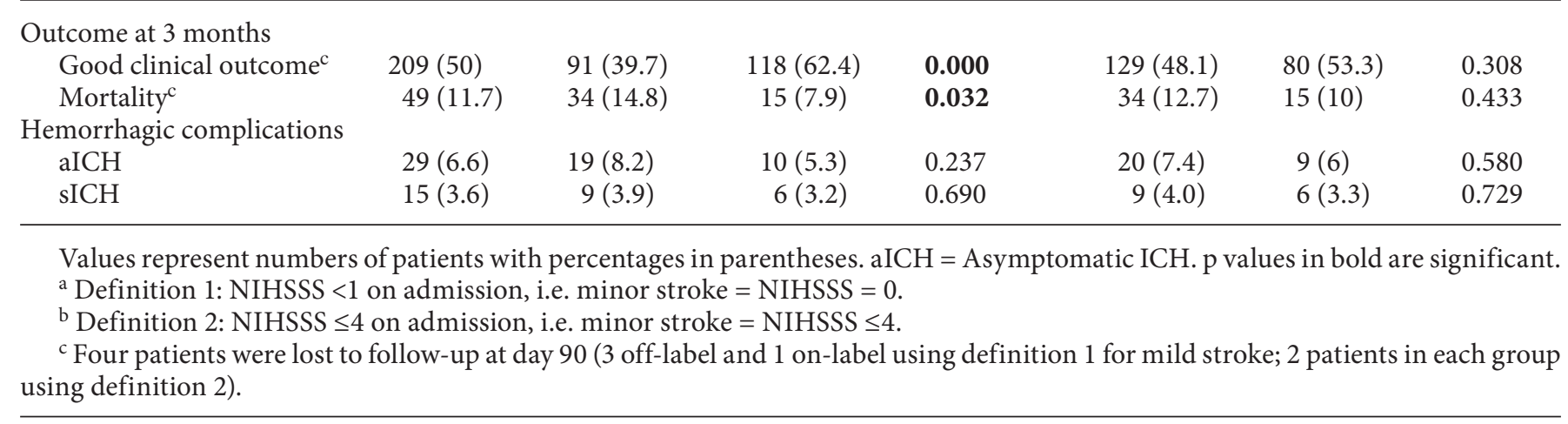

Table 4. Impact of separate OLCs in multivariate regression analysis

\begin{tabular}{|c|c|c|c|c|c|c|}
\hline & \multicolumn{2}{|c|}{ Poor clinical outcome } & \multicolumn{2}{|l|}{ Mortality } & \multicolumn{2}{|l|}{ sICH } \\
\hline & OR (95\% CI) & $\mathrm{p}$ value & OR (95\% CI) & $\mathrm{p}$ value & OR $(95 \% \mathrm{CI})$ & $\mathrm{p}$ value \\
\hline Off-label therapy & $2.56(1.62-4.06)$ & 0.000 & $0.559(0.167-1.871)$ & 0.345 & - & - \\
\hline Age $>80$ years & $1.94(1.16-3.26)$ & 0.012 & $0.714(0.152-3.351)$ & 0.669 & $2.49(0.88-7.02)$ & 0.086 \\
\hline Previous stroke and diabetes & $5.12(0.54-49.05)$ & 0.157 & - & - & - & - \\
\hline NIHSSS $>25$ & - & - & - & - & $7.196(0.76-68.63)$ & 0.086 \\
\hline Previous stroke $\leq 3$ months & - & - & - & - & $9.619(0.94-98.38)$ & 0.056 \\
\hline
\end{tabular}

For each OLC, a separate model for all outcome end points was calculated. Each model was adjusted for baseline characteristics and for factors showing a trend in univariate analysis. $\mathrm{p}$ values in bold are significant.

(14.5\%) had 2 and 11 patients (2.6\%) had 3 concomitant OLCs. In 1 patient (0.2\%), 4 OLCs (age $>80$ years, blood pressure $>185 / 110 \mathrm{~mm} \mathrm{Hg}$ and/or use of intravenous antihypertensives, previous stroke and diabetes, current therapy with anticoagulants) were found by the time of thrombolysis (no sICH, mRS of 3 at 90 days). Regression analysis regarding outcome and sICH depending on the number of coexisting OLCs (using definition 1) demonstrated an increasing OR for poor clinical outcome the more contraindications were present, whereas no such relation existed for sICH. The OR for poor clinical outcome at 3 months for 1 OLC was 2.04 (95\% CI 1.32-3.14; $\mathrm{p}=$ 0.001 ), which increased to 2.85 (95\% CI 1.57-5.18; $\mathrm{p}=$ $0.001)$ with 2 coexisting OLCs and 16.08 (95\% CI $2.02-$ $128.21 ; \mathrm{p}=0.009$ ) with 3 OLCs.

\section{Discussion}

Experienced stroke centers use tPA beyond existing license restrictions but few data are available on the outcome and safety of off-label thrombolysis. Several studies have focussed on individual OLCs but only few publications have addressed outcome and safety with tPA contraindications in general $[3,8,9]$. We analyzed how many patients in our institution received off-label thrombolysis according to the European product license and compared their clinical outcome and safety data to those of patients treated on-label.

Overall, 55\% of our thrombolysis patients would not have been treated if we had adhered strictly to the European product license for $\mathrm{tPA}$. As a direct consequence of 
ignoring the respective license restrictions, off-label patients were older, arrived more often within an extended time window, had higher blood pressure on hospital admission and were more likely to have a history of arterial hypertension and previous strokes. Higher rates of previous atrial fibrillation and cardioembolic strokes among the off-label patients are probably related to the higher age in this subgroup (table 2).

In general, license restrictions can be divided into two distinct groups. The first group excludes patients with a presumed favorable outcome - mainly patients with mild strokes - in whom the risks of treatment might exceed the potential benefit. The second group of restrictions aim to avoid treatment in patients with an elevated risk of complications (i.e. patients $>80$ years). In an analysis that combines both of these groups as 'off-label', the first group may partly compensate for worse outcome effects driven by the second group. Therefore, the definition of 'minor stroke' is of particular importance. Neither international guidelines $[7,10]$ nor European or Food and Drug Administration licenses give an exact definition of the term 'minor stroke'. The wording in the license relates to the inclusion criteria of the approval-relevant National Institute of Neurological Disorders and Stroke trial, which enrolled patients with an NIHSSS of at least 1 [11]. However, a multitude of different definitions are used in the literature, with the most commonly used threshold being an NIHSSS of $\leq 4$ [12-18]. Therefore, we used both definitions of minor stroke in this study to directly analyze their effect on outcome and sICH rates between patients treated on- and off-label.

Considering patients with an initial NIHSSS of $\leq 4$ as off-label, there was no statistically significant difference in the number of patients who achieved a good clinical outcome between patients treated off- and on-label. This corresponds well with the results presented by Meretoja et al. [3], who recently compared outcome and ICH rates in patients treated with off-label and on-label IVT using the same definition for minor stroke. In addition, applying this definition in our study, the favorable outcome in our off-label patients (48.1\%) was comparable to that in the above-mentioned study (54.5\%) [3]. In contrast, defining only NIHSSS $<1$ as off-label and thus shifting patients with an NIHSSS of 1-4 to the on-label group naturally reduces the rate of favorable outcomes in the offlabel group (39.7\%). At the same time, it 'improves' outcome in the on-label population. This shift leads to an overall significantly worse outcome in the off-label compared to on-label patients and underlines the hypothesis that including mild strokes in the cohort of all off-label patients can lead to a serious bias of the overall off-label outcome.

In our cohort, age $>80$ years was not only the most common OLC but also the only specific independent predictor for poor outcome in multivariate regression analysis. Among the OLCs, age $>80$ years is the best examined predictor for outcome. Recently, Rubiera et al. [4] compared patients treated according to Safe Implementation of Thrombolysis in Stroke-Monitoring Study criteria with patients not fulfilling those criteria. They also identified age $>80$ years as the most important factor for worse outcome in off-label patients. Exclusion of patients $>80$ years led to comparable outcomes in both groups. The finding that thrombolysed patients $>80$ years have a worse outcome was shown in many previous studies [1924]. However, this is expected since age is one of the most important outcome predictors for stroke patients irrespective of tPA treatment and therefore should not lead to the assumption that IVT is not beneficial in this patient subgroup. This is also supported by recent analyses of patients from the Virtual International Stroke Trials Archive and Safe Implementation of Treatments in Stroke databases [25], and ongoing trials such as the Third International Stroke Trial and the Thrombolysis in Elderly Stroke Patients in Italy multicenter trial will soon address this issue.

In concordance with the previously mentioned studies, our data did not reveal significant differences in sICH rates between on- and off-label patients independently of the off-label definition used. Though age $>80$ years, NIHSSS $>25$ and previous stroke showed a trend, none of the specific license contraindications were significantly associated with a higher rate of sICH.

Even though one isolated contraindication might not seriously affect the outcome of IVT patients, there are few data on the influence of multiple concomitant OLCs in a single patient. In our study, the OR for poor clinical outcome but not for sICH increased with the number of concomitant contraindications. It doubled in patients with 1 OLC compared to on-label patients and almost tripled when 2 OLCs were present. In patients with 3 OLCs, it increased up to 16 -fold. Although the number of patients with 3 OLCs is small and this effect might be overestimated, our results indicate that patients with 2 or more concomitant OLCs should be treated with caution.

Our study has limitations, most notably the singlecenter approach and the retrospective design. However, to the best of our knowledge it is the first study to analyze the effect of different definitions of minor stroke on outcome and safety in patients given off-label thrombolysis. 
In conclusion, off-label therapy is frequently applied at our center and is not associated with higher complication rates. More than half of our patients would not have been treated if we had strictly followed the European license. An exact definition of individual contraindications (particularly 'minor stroke') is essential to evaluate the clinical outcome of patients treated off-label and to compare the results of different studies. Beside age $>80$ years, a known poor prognostic factor in stroke patients in general, no specific OLC was associated with poor outcome. Our data suggest that the criteria in the European tPA license might be too restrictive.

\section{Disclosure Statement}

M.K., H.B.H. and S.S. received travel grants from Boehringer Ingelheim, the manufacturer of recombinant tPA. S.S. is a member of the advisory board and received speaker honoraria from Boehringer Ingelheim. No funding was received for the present study.

\section{References}

1 Hacke W, Kaste M, Fieschi C, von Kummer R, Davalos A, Meier D, Larrue V, Bluhmki E, Davis S, Donnan G, Schneider D, Diez-Tejedor E, Trouillas P: Randomised double-blind placebo-controlled trial of thrombolytic therapy with intravenous alteplase in acute ischaemic stroke (ECASS II). Second European-Australasian Acute Stroke Study Investigators. Lancet 1998;352:1245-1251.

2 Hacke W, Kaste M, Fieschi C, Toni D, Lesaffre E, von Kummer R, Boysen G, Bluhmki E, Hoxter G, Mahagne MH, et al: Intravenous thrombolysis with recombinant tissue plasminogen activator for acute hemispheric stroke. The European Cooperative Acute Stroke Study (ECASS). JAMA 1995;274: 1017-1025.

3 Meretoja A, Putaala J, Tatlisumak T, Atula S, Artto V, Curtze S, Happola O, Lindsberg PJ, Mustanoja S, Piironen K, Pitkaniemi J, Rantanen K, Sairanen T, Salonen O, Silvennoinen H, Soinne L, Strbian D, Tiainen M, Kaste M: Off-label thrombolysis is not associated with poor outcome in patients with stroke. Stroke 2010;41:1450-1458.

4 Rubiera M, Ribo M, Santamarina E, Maisterra O, Delgado-Mederos R, Delgado P, Ortega G, Alvarez-Sabin J, Molina CA: Is it time to reassess the SITS-MOST criteria for thrombolysis?: a comparison of patients with and without SITS-MOST exclusion criteria. Stroke 2009;40:2568-2571.

5 Hacke W, Kaste M, Bluhmki E, Brozman M, Davalos A, Guidetti D, Larrue V, Lees KR, Medeghri Z, Machnig T, Schneider D, von Kummer R, Wahlgren N, Toni D: Thrombolysis with alteplase 3 to 4.5 hours after acute ischemic stroke. N Engl J Med 2008;359: 1317-1329.
6 Kohrmann M, Juttler E, Fiebach JB, Huttner HB, Siebert S, Schwark C, Ringleb PA, Schellinger PD, Hacke W: MRI versus CTbased thrombolysis treatment within and beyond the $3 \mathrm{~h}$ time window after stroke onset: a cohort study. Lancet Neurol 2006;5: 661-667.

7 European Stroke Organisation (ESO) Executive Committee; ESO Writing Committee: Guidelines for management of ischaemic stroke and transient ischaemic attack 2008. Cerebrovasc Dis 2008;25:457-507.

8 Aleu A, Mellado P, Lichy C, Kohrmann M, Schellinger PD: Hemorrhagic complications after off-label thrombolysis for ischemic stroke. Stroke 2007;38:417-422.

9 Wahlgren N, Ahmed N, Davalos A, Ford GA, Grond M, Hacke W, Hennerici MG, Kaste M, Kuelkens S, Larrue V, Lees KR, Roine RO, Soinne L, Toni D, Vanhooren G: Thrombolysis with alteplase for acute ischaemic stroke in the Safe Implementation of Thrombolysis in Stroke-Monitoring Study (SITS-MOST): an observational study. Lancet 2007;369: 275-282.

10 Adams HP Jr, del Zoppo G, Alberts MJ, Bhatt DL, Brass L, Furlan A, Grubb RL, Higashida RT, Jauch EC, Kidwell C, Lyden PD, Morgenstern LB, Qureshi AI, Rosenwasser RH, Scott PA, Wijdicks EF: Guidelines for the early management of adults with ischemic stroke: a guideline from the American Heart Association/American Stroke Association Stroke Council, Clinical Cardiology Council, Cardiovascular Radiology and Intervention Council, and the Atherosclerotic Peripheral Vascular Disease and Quality of Care Outcomes in Research Interdisciplinary Working Groups: the American Academy of Neurology affirms the value of this guideline as an educational tool for neurologists. Stroke 2007;38:1655-1711.
11 Tissue plasminogen activator for acute ischemic stroke. The National Institute of Neurological Disorders and Stroke rt-PA Stroke Study Group. N Engl J Med 1995;333:15811587.

12 Clark WM, Wissman S, Albers GW, Jhamandas JH, Madden KP, Hamilton S: Recombinant tissue-type plasminogen activator (alteplase) for ischemic stroke 3 to 5 hours after symptom onset. The ATLANTIS Study: a randomized controlled trial. Alteplase Thrombolysis for Acute Noninterventional Therapy in Ischemic Stroke. JAMA 1999; 282:2019-2026.

13 Cocho D, Belvis R, Marti-Fabregas J, Molina-Porcel L, Diaz-Manera J, Aleu A, Pagonabarraga J, Garcia-Bargo D, Mauri A, MartiVilalta JL: Reasons for exclusion from thrombolytic therapy following acute ischemic stroke. Neurology 2005;64:719-720.

14 Katzan IL, Hammer MD, Hixson ED, Furlan AJ, Abou-Chebl A, Nadzam DM: Utilization of intravenous tissue plasminogen activator for acute ischemic stroke. Arch Neurol 2004; 61:346-350.

15 Khatri P, Kleindorfer DO, Yeatts SD, Saver JL, Levine SR, Lyden PD, Moomaw CJ, Palesch YY, Jauch EC, Broderick JP: Strokes with minor symptoms. An exploratory analysis of the National Institute of Neurological Disorders and Stroke recombinant tissue plasminogen activator trials. Stroke 2010;41: 2581-2586.

16 Kleindorfer D, Kissela B, Schneider A, Woo D, Khoury J, Miller R, Alwell K, Gebel J, Szaflarski J, Pancioli A, Jauch E, Moomaw C, Shukla R, Broderick JP: Eligibility for recombinant tissue plasminogen activator in acute ischemic stroke: a population-based study. Stroke 2004;35:e27-e29. 
17 Nedeltchev K, Schwegler B, Haefeli T, Brekenfeld C, Gralla J, Fischer U, Arnold M, Remonda L, Schroth G, Mattle HP: Outcome of stroke with mild or rapidly improving symptoms. Stroke 2007;38:2531-2535.

18 Rajajee V, Kidwell C, Starkman S, Ovbiagele B, Alger JR, Villablanca P, Vinuela F, Duckwiler G, Jahan R, Fredieu A, Suzuki S, Saver JL: Early MRI and outcomes of untreated patients with mild or improving ischemic stroke. Neurology 2006;67:980-984.

19 Berrouschot J, Rother J, Glahn J, Kucinski T, Fiehler J, Thomalla G: Outcome and severe hemorrhagic complications of intravenous thrombolysis with tissue plasminogen activator in very old ( $>$ or $=80$ years) stroke patients. Stroke 2005;36:2421-2425.
20 Engelter ST, Bonati LH, Lyrer PA: Intravenous thrombolysis in stroke patients of $>$ or $=80$ versus $<80$ years of age - a systematic review across cohort studies. Age Ageing 2006;35:572-580.

21 Engelter ST, Reichhart M, Sekoranja L, Georgiadis D, Baumann A, Weder B, Muller F, Luthy R, Arnold M, Michel P, Mattle HP, Tettenborn B, Hungerbuhler HJ, Baumgartner RW, Sztajzel R, Bogousslavsky J, Lyrer PA: Thrombolysis in stroke patients aged 80 years and older: Swiss survey of IV thrombolysis. Neurology 2005;65:1795-1798.

22 Sylaja PN, Cote R, Buchan AM, Hill MD Thrombolysis in patients older than 80 years with acute ischaemic stroke: Canadian Alteplase for Stroke Effectiveness Study. J Neurol Neurosurg Psychiatry 2006;77: 826-829.
23 Tanne D, Gorman MJ, Bates VE, Kasner SE, Scott P, Verro P, Binder JR, Dayno JM, Schultz LR, Levine SR: Intravenous tissue plasminogen activator for acute ischemic stroke in patients aged 80 years and older: the tPA stroke survey experience. Stroke 2000; 31:370-375.

24 van Oostenbrugge RJ, Hupperts RM, Lodder $\mathrm{J}$ : Thrombolysis for acute stroke with special emphasis on the very old: experience from a single Dutch centre. J Neurol Neurosurg Psychiatry 2006;77:375-377.

25 Mishra NK, Ahmed N, Andersen G, Egido JA, Lindsberg PJ, Ringleb PA, Wahlgren NG, Lees KR: Thrombolysis in very elderly people: controlled comparison of SITS International Stroke Thrombolysis Registry and Virtual International Stroke Trials Archive. BMJ 2010;341:c6046. 